Hydrology and Earth System Sciences, 5(3), 433-450 (2001) C C EGS

\title{
Seasonality, water quality trends and biological responses in four streams in the Cairngorm Mountains, Scotland
}

\author{
C. Soulsby, R. Malcolm, C. Gibbins and C.Dilks \\ Department of Geography and Environment, University of Aberdeen, Aberdeen, AB24 3UF, UK
}

Email for corresponding author: c.soulsby@abdn.ac.uk

\begin{abstract}
The chemical composition and invertebrate communities found in four streams in the Cairngorms, Scotland, were monitored between 19851997. Stream waters were mildly acidic (mean pH ca. 6.5), with low alkalinity (mean acid neutralising capacity varying from $35-117$ meq $1^{-1}$ ) and low ionic strength. Subtle differences in the chemistry of each stream were reflected in their invertebrate faunas. Strong seasonality in water chemistry occurred, with the most acid, low alkalinity waters observed during the winter and early spring. This was particularly marked during snowmelt between January and April. In contrast, summer flows were usually groundwater dominated and characterised by higher alkalinity and higher concentrations of most other weathering-derived solutes. Seasonality was also clear in the invertebrate data, with Canonical Correspondence Analysis (CCA) separating seasonal samples along axes related to water temperature and discharge characteristics. Inter-annual hydrological and chemical differences were marked, particularly with respect to the winter period. Invertebrate communities found in each of the streams also varied from year to year, with spring communities significantly more variable $(P<0.01)$ than other seasons (quantified using Euclidean distance on CCA ordinations).

Hydrochemical trends over the study period were analysed using a seasonal Kendall test, LOcally WEighted Scatterplot Smoothing (LOWESS) and graphical techniques. These indicated that a reduction in sulphate concentrations in stream water is occurring, consistent with declining levels of atmospheric deposition. This may be matched by increases in $\mathrm{pH}$ and declining calcium concentrations, though available evidence is inconclusive. Other parameters, such as chloride, total organic carbon and zinc, reveal somewhat random patterns, probably reflecting irregular variations in climatic factors and/or atmospheric deposition. Previous studies have shown that the stream invertebrate communities have remained stable over this period (i.e. no significant linear trends) and show no evidence of acid-related impoverishment. Thus, over longer timescales invertebrates in these streams appear robust to the short-term (seasonal and inter-annual) environmental variability and long-term (decadal) chemical changes identified.
\end{abstract}

Keywords: hydrochemistry, hydrology, trends, macroinvertebrates, uplands, Cairngorms, acidification

\section{Introduction}

Over the past two decades, interest in environmental change has resulted in numerous studies designed to monitor catchment hydrochemical responses and their ecological implications (Hornung et al., 1990; Moldan and Cerny, 1994; Lancaster et al., 1996; Neal et al., 1997). The reversibility of stream acidification in response to declining sulphur (S) emissions and the impact of anthropogenically forced climatic changes are two areas of particular interest (Aulenbach et al., 1996; Stoddard et al., 1999). As longerterm (i.e. decadal) data sets have become available, many facets of stream hydrochemical behaviour have become apparent (Robson and Neal, 1996; Reynolds et al., 1997). Long-term directional changes in stream hydrochemistry have been observed in response to reductions in levels of sulphate $\left(\mathrm{SO}_{4}\right)$ deposition (Harriman et al., 1995; Tipping et al., 1998). Superimposed on these, marked inter-annual variation in seasonal patterns has been observed; this variation can often be explained by longer-term climatic variability (Robson and Neal, 1996; Soulsby et al., 1997a). Within such longer-term climatic variations, cyclical patterns can often be observed in hydrological behaviour (Grew and Werritty, 1995). Over shorter timescales (i.e. days, weeks), variation in catchment hydrological pathways can have a major effect on stream water chemistry and affect water quality trends (Langan et al., 1997; Miller and Hirst, 1998).

The biological responses to chemical change have also 
been investigated across a range of spatial and temporal scales, and with respect to different groups of organisms (Battarbee et al., 1988; Edwards et al., 1991; Juggins et al., 1996; Lancaster et al., 1996; Buckton et al., 1998). Disentangling the effects of long-term and short-term changes at different spatial scales, however, has proved extremely difficult (Ormerod and Jenkins, 1994). Consequently, patterns and processes may be highly catchment-specific and caution needs to be exercised over the transferability of results to different spatial and temporal scales and to other locations (Burt, 1994; Neal et al., 1997; Soulsby et al., 2000). Nevertheless, hydrochemical changes over hydrological events, seasons and longer time periods can provide invaluable insights into the external and internal processes influencing catchment hydrochemistry. Moreover, as long-term biological data sets become available and multivariate statistical techniques are developed, insights into biological responses are also becoming possible. Many long-term monitoring programmes relate to a spatially restricted scale of a single stream or catchment. There is an implicit assumption that such catchments are broadly representative of a wider geographical area, though such assumptions are rarely tested (cf. Burt, 1994). Although paired catchment studies which investigate the influence of land use differences have been standard practice in UK hydrology, long-term hydrological, hydrochemical and ecological studies of similar adjacent catchments are less common.

In this paper, longer-term water quality data sets (> 13 years) are examined, along with associated macroinvertebrate data, for four streams in the western Cairngorm mountains, Scotland. The Cairngorms form the largest area of montane environment in the UK and experience a transitional sub-arctic climate that is considered sensitive to acid deposition and climatic change (Gordon $e t$ al., 1998). This sensitivity is reflected in inter-annual variability in levels of snowpack accumulation which exerts a strong influence on the magnitude, distribution and quality of streamflows during the winter and spring (Soulsby et al., 1997a; Dunn and Langan, 1998). There is also evidence from streamwater temperature records that winter and spring temperatures have been increasing in the area over the past two to three decades (Langan et al., 2001).

The mountains are dominated by granitic rocks and acid sensitive soils and high altitude lochs have shown clear evidence of acidification over the last 150 years (Jones et al., 1993). Although current levels of acid deposition are modest and $\mathrm{S}$ deposition is declining (Soulsby et al., 1997b), concern remains over increasing nitrogen $(\mathrm{N})$ loads (Jenkins, 1999; Helliwell et al., 2001). The hydrochemical and macroinvertebrate data sets presented here allow, for the first time, an examination of longer-term inter-annual variation in hydrochemical conditions in adjacent Cairngorm catchments. The main aims of this paper are, therefore, to: (a) describe and compare the hydrochemical and invertebrate community characteristics of the four streams; (b) examine seasonal, inter-annual and long term variation in the hydrology and hydrochemistry of the streams; and (c) evaluate the controls on temporal variation and their implications for invertebrate communities.

\section{Study area}

The four study streams drain part of the western flank of the Cairngorm mountains in northern Scotland. They are tributaries of the River Feshie, itself a tributary of the River Spey (Fig. 1). One of the streams, the Allt a'Mharcaidh,

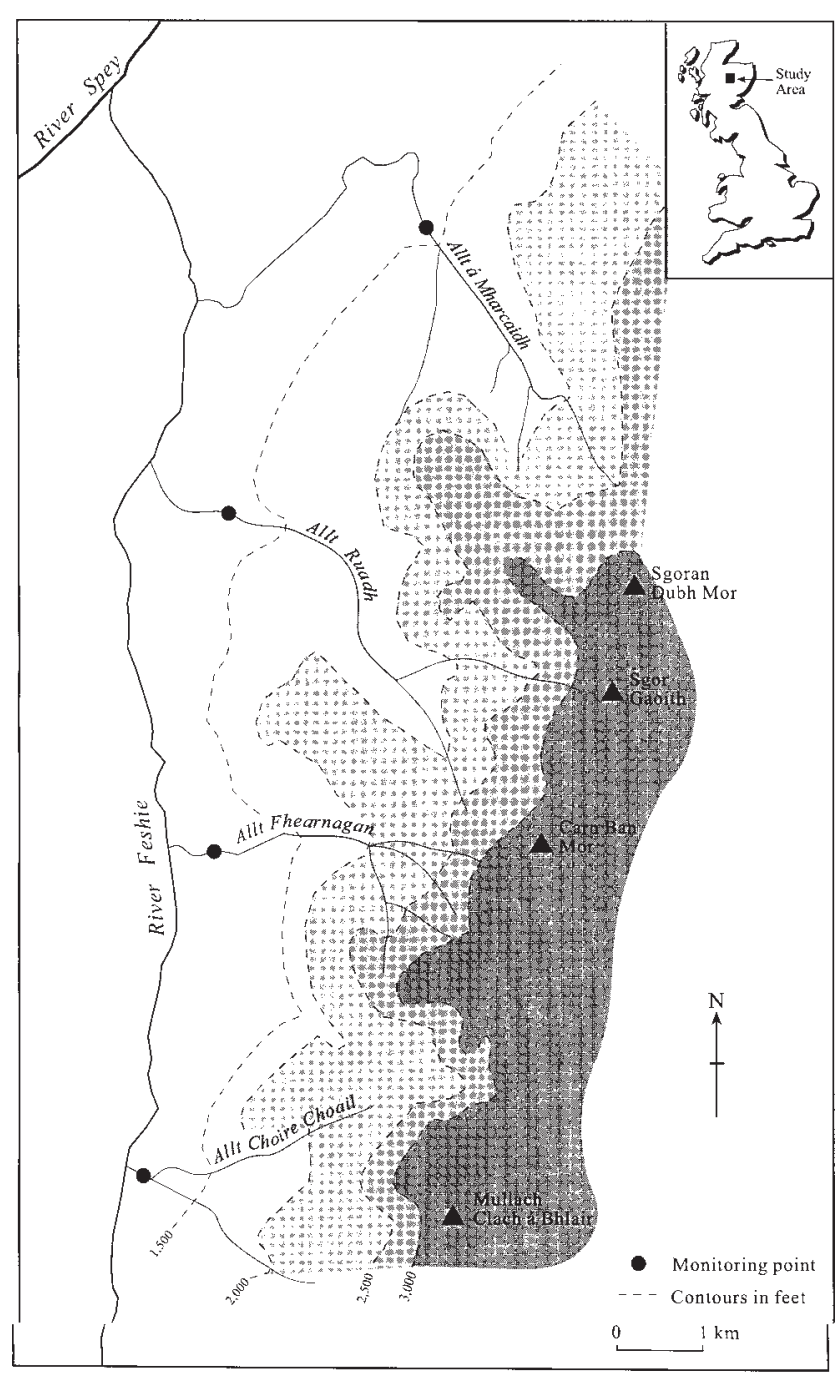

Fig.1. Study streams in the western Cairngorms 
Table 1. Characteristics of the four western Cairngorm study streams

\begin{tabular}{|c|c|c|c|c|c|c|c|c|}
\hline Stream & $\begin{array}{l}\text { National Grid } \\
\text { Ref. }\end{array}$ & $\begin{array}{l}\text { Area } \\
\left(\mathrm{km}^{2}\right)\end{array}$ & $\begin{array}{l}\text { Altitudinal } \\
\text { range }(m)\end{array}$ & $\begin{array}{l}\text { Slope } \\
\left(m \mathrm{~km}^{-1}\right)\end{array}$ & $\begin{array}{l}\text { Stream } \\
\text { order }\end{array}$ & $\begin{array}{l}\text { Mean } \\
\text { water } \\
\text { temp }\left({ }^{\circ} \mathrm{C}\right.\end{array}$ & $\begin{array}{l}\text { Deposition } \\
\text { Keq } H^{+} a^{-1}\end{array}$ & $\begin{array}{l}\text { Dominant } \\
\text { Geology }\end{array}$ \\
\hline Allt a'Mharcaidh & NH879050 & 10 & $280-1111$ & 50 & 3 & 6.46 & 2.2 & Granite \\
\hline Allt Ruadh & NH859010 & 11 & $340-1118$ & 100 & 3 & 6.20 & 2.2 & Granite \\
\hline Allt Fhernagan & NH851971 & 8 & $320-1052$ & 36 & 3 & 6.89 & 2.2 & Granite \\
\hline Allt Coire Chaoil & NH847934 & 7 & $360-1019$ & 66 & 3 & 7.77 & 2.2 & Schist \\
\hline
\end{tabular}

forms part of the UK Acid Waters Monitoring Network ((AWMN); Monteith and Evans, 2000) and has been studied extensively. The streams, which are all third order, drain catchments which span altitudinal ranges of $c a$. 300-1100 m and range from $7-11 \mathrm{~km}^{2}$ in area (Table 1). They are characterised by steep altitudinal gradients and have mean annual precipitation inputs that vary from $900 \mathrm{~mm}$ in the lower valleys to over $1500 \mathrm{~mm}$ at altitudes above $1000 \mathrm{~m}$. Mean monthly air temperatures (at $575 \mathrm{~m}$ ) range from $1.2^{\circ} \mathrm{C}$ in February to $10.3^{\circ} \mathrm{C}$ in July. Snow is often the dominant form of precipitation during the winter months (November to February) and typically accounts for $30 \%$ of the mean annual catchment precipitation (Soulsby et al., 1997a).

The geology of the Cairngorms is predominantly grantic, though the Allt Coire Chaoil catchment is underlain by schists. Both rock types give rise to acidic soils which have often developed on various drift deposits. In general, soils vary with altitude and topography: alluvial soils dominate the riparian areas $<10 \mathrm{~m}$ from the stream channel; below $800 \mathrm{~m}$ on steeper slopes humus iron podzols prevail, though these grade to deep peats in flatter areas. Both these soils form on a range of colluvial drift deposits which can exceed $10 \mathrm{~m}$ depth in places. Above $800 \mathrm{~m}$, poorly developed alpine podzols and regosols mantle frost shattered drift which is generally freely draining (Davies et al., 1993). The distribution of soils is reflected in the dominant vegetation assemblages: azalea-alpine heath dominates above $800 \mathrm{~m}$, northern blanket bog characterises the peats and heather (Calluna) moorland is found on the humus iron podzols. The lower slopes of each catchment have a small $(<5 \%)$ area of mature forest cover dominated by native Scots pine (Pinus sylvestris).

Acid deposition in the area is modest. Non-marine $S$ inputs (currently $c a .7 .0 \mathrm{~kg} \mathrm{ha}^{-1} \mathrm{a}^{-1}$ ) have been declining over the last two decades (Soulsby et al., 1997b) although there are rising concerns over increasing levels of $\mathrm{N}$ deposition (currently c. $10.8 \mathrm{~kg} \mathrm{ha}^{-1} \mathrm{a}^{-1}$ ). While palaeolimnological evidence from high altitude $(>900 \mathrm{~m})$ lochs in the Cairngorms implies major alterations in species composition and diversity over the last 150 years as a result of acidification (Jones et al., 1995), macroinvertebrate species richness of the four streams is relatively high, with numerous acid-sensitive taxa present (Lancaster et al., 1996; Soulsby et al., 1997b). Moreover, the streams support reasonable populations of salmonid fish (Harriman et al., 1990) implying acidification has had a less marked impact.

The streams have similar hydrological regimes, though flows have only been gauged accurately in the Allt a'Mharcaidh. Mean annual run-off in the Allt a'Mharcaidh is around $850 \mathrm{~mm}$, with annual evaporation losses of around $350 \mathrm{~mm}$. Hydrological flow paths in the Allt a'Mharcaidh catchment have been extensively investigated (Wheater $e t$ al., 1993; Jenkins et al., 1993; Soulsby et al., 1998, 1999, 2000) and provide a general picture of the processes likely to be important in the other catchments. The annual hydrological regime is dominated by the winter period where substantial snow pack accumulation can result in large snowmelt events in the late winter and early spring (JanuaryApril). Such events often involve an element of rainfall. For the rest of the year, overland and preferential flow, particularly from peaty soils in the lower catchment dominates the storm hydrograph response (Fig. 2). The large areas of freely draining alpine soils appear to contribute a substantial amount of groundwater recharge. Complex groundwater flow systems in the catchments discharge at local springs in the upper slopes of the catchment or into the stream channel and riparian zones in the valley bottom (Soulsby et al., 1998, 1999). Geochemically-based hydrograph separation and semi-distributed modelling implies that $40-60 \%$ of annual run-off is sustained from 


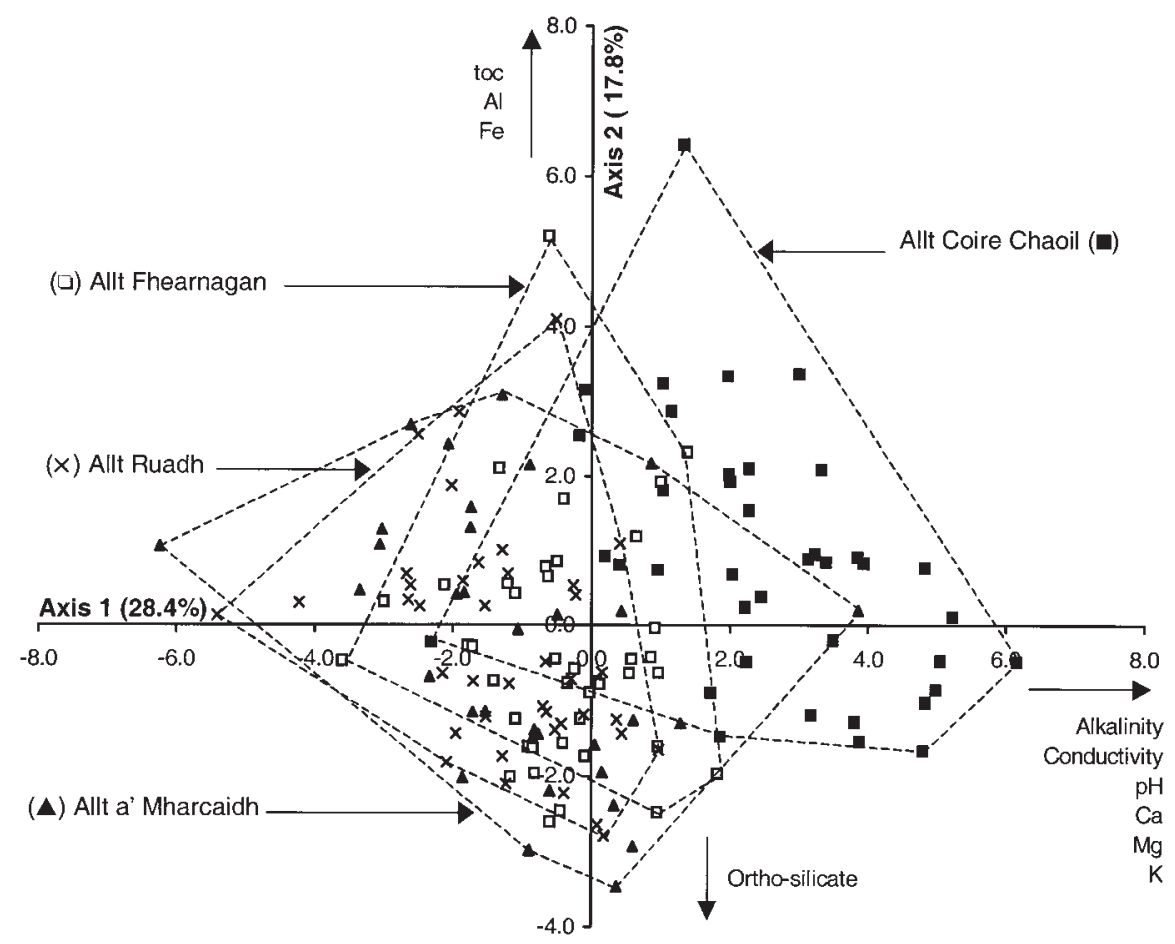

Fig. 2. Principal components ordination of stream chemical data

groundwater sources (Soulsby and Dunn, 2001). This groundwater is relatively well-buffered and may help explain the more limited impact of acidification in these streams.

\section{Methods}

Hydrochemical and invertebrate data were collected from a single site in each catchment. Sampling sites were all 2-3 km upstream from respective confluences with the Feshie (Fig. 1) and all at a similar altitude. Channel widths at sampling sites ranged from 3.4 to $5.2 \mathrm{~m}$. Stream water samples were collected at monthly intervals between 1985 and 1997 from each site. These were analysed at the laboratories of the Scottish Environment Protection Agency (SEPA) using standard methods (Doughty, 1989). All samples were collected within two hours on the same calendar day. Consequently, over the 13-year study period, over 150 samples were collected from each stream. In the Allt a'Mharcaidh, stream flows were also measured as part of the AWMN using a pressure transducer in a rated natural section and stream temperatures were logged at 15-minute intervals. Stage boards in the three neighbouring catchments allowed cross-correlation with the Allt a'Mharcaidh site which provided a means of estimating mean daily flows and the flow when samples were collected.

Macroinvertebrate kick-samples were collected from each site in spring (April), summer (July) and autumn (October) of each year by SEPA. Invertebrates were collected at the same time as the chemistry samples. Kick-sampling duration was three minutes, with the fieldworker progressing diagonally across the channel incorporating all habitats present. Invertebrates were counted and identified to various taxonomic levels. Long-term data collection and analytical programmes inevitably involve different personnel. To help avoid problems caused by different workers identifying invertebrates, difficult groups (Chironomidae, Simuliidae, Tipulidae and annelids) were identified only to family level; all others were identified to species. Invertebrate sample processing was quality controlled using SEPA protocols.

Catchment chemistries were compared using Principal Components Analysis (PCA). This allowed key differences between catchments and seasons to be identified. Long-term temporal patterns were investigated using a seasonal Kendall test along with LOcally WEighted Scatterplot Smoothing (LOWESS). The former is a non-parametric test for trends in data that show monotonic variations (Waters and Jenkins, 1992; Aulenbach et al., 1996). This is particularly useful for analysis of stream water data where seasonality is marked, as the test is suited to non-normal distributions and is robust against extreme values (Hirsch et al., 1982; Reynolds et al., 1997). This presumes, however, that data are either exhibiting an increasing or decreasing trend, or remaining constant. Robson and Neal (1989) show that such assumptions may not be true for stream water quality data 
which may show cyclic or random variations in relation to inter-annual climatic fluctuations or changes in atmospheric deposition. Thus, they advocate visual interpretation of plots using LOWESS analysis. This fits a locally weighted quadratic polynomial to smooth out trend lines and the technique is fully discussed by Robson and Neal (1996). Caution is needed in interpreting the trends at the start and end of the record period as fewer points are used to generate the curves.

Invertebrate community patterns were analysed using Canonical Correspondence Analysis (CCA; ter Braak, 1986; Palmer, 1993). CCA ordination allows assessment of the relationships between biological and environmental data, specifically the extent to which variation in biological data can be accounted for by the measured environmental variables. On CCA ordinations, environmental variables are represented by arrows whose lengths reflect their relative importance in structuring the biological sample data. Two CCA ordinations were performed. The first used data for all four catchments and assessed invertebrate community patterns with respect to chemical and discharge conditions on the day invertebrate samples were collected. The second analysis focussed on the Allt a' Mharcaidh and assessed the relationship between invertebrate community structure and chemical and discharge conditions over the two months prior to respective invertebrate samples being collected. Conditions were characterised using indices of variation. These indices quantified the frequency with which variables exceeded or fell below certain thresholds. Threshold values were taken from a range of published observational and experimental studies (Sagar, 1986; Edwards et al., 1990; Mason, 1990; Clausen and Biggs, 1997).

Prior to CCA analysis, variables exhibiting strong to moderate inter-correlations were removed. Forward selection (ter Braak and Verdonschot, 1995) was then used to identify which of the remaining variables exerted a significant influence on the invertebrate data. Temperature, calcium (Ca), alkalinity, total organic carbon (TOC), discharge and ortho-silicate were identified as significant (Monte Carlo permutation test at $p<0.05$ ). The variation explained by the first two axes of the CCA ordination using these six variables was only $1 \%$ less than when all 16 discharge and chemical variables were included. Final ordinations were produced using these six variables. To compare invertebrate community composition, final CCA axis scores were re-scaled using Hill's scaling (Jongman et al., 1995). This results in axes scaled by standard deviation (s.d.) units, with samples separated by more than four s.d. units exhibiting, in general, no species in common (Juggins et al., 1996).

\section{Results and discussion}

\section{GENERAL HYDROCHEMICAL CHARACTERISTICS OF STREAMWATERS}

The hydrochemical characteristics of the study streams are summarised in Table 2. All had generally similar chemistries, though the geological difference of the Allt Coire Chaoil resulted in higher concentrations of most weathering-derived species. This is evident in the PCA ordination (Fig. 2), with the Allt Coire Chaoil separated from the other catchments along the axis describing trends in alkalinity, conductivity and $\mathrm{pH}$. In general, all the streams were slightly acidic and streamwaters were of very low ionic strength with low alkalinity. Through comparisons with sodium:chloride $(\mathrm{Na}: \mathrm{Cl})$ ratios in precipitation, $\mathrm{Na}$ was shown to be mainly (c. 70\%) derived from marine (atmospheric) sources and was the dominant base cation in all four streams. Concentrations of other base cations were low, though higher concentrations were observed in the Allt Coire Chaoil; this was particularly marked for magnesium $(\mathrm{Mg})$ and $\mathrm{Ca}$, which in all streams was mainly derived from marine (c. 70\%) and non-marine (c. 95\%) sources, respectively. Marinederived $\mathrm{Cl}$ formed the dominant anion in all four streams, though $\mathrm{SO}_{4}$ concentrations accounted for around $25 \%$ of the acid anion composition and was predominantly nonmarine (c. $80 \%)$ in origin. Total Organic Carbon concentrations were generally low $\left(<2 \mathrm{mg} \mathrm{l}^{-1}\right)$ in the three northern streams, whilst levels were again elevated in the Allt Coire Chaoil. Nitrate $\left(\mathrm{NO}_{3}\right)$ concentrations were generally low, with higher concentrations generally being observed in spring snowmelt events and after warm summer periods. Trace metal concentrations were low in all four streams, with aluminium ( $\mathrm{Al})$ and iron $(\mathrm{Fe})$ levels being strongly correlated with TOC implying that transport as organic complexes was important.

All chemical determinands showed a wide range of variability (Table 2), with much of this being explained by changes in hydrological pathways (Fig. 3). At high flows, when near surface hydrological pathways operate in response to precipitation or snowmelt events, stream waters tend to be more acidic, depleted in $\mathrm{Ca}$ and silicate and enriched in TOC and Al (Wade et al., 1999). In contrast, when base flows are sustained by a range of deeper groundwater sources, the streams are circum-neutral and are enriched in alkalinity and silicate. Despite this, Fig. 3 indicates that the relationships between chemistry and flow are not simple in Cairngorm headwater streams. This is particularly so for soil-derived species such as TOC and Al where the confounding influence of seasonal variations in catchment hydrological and biogeochemical processes may be marked. 
Table 2. Mean and range of water quality parameters in the study streams. All units $\mu$ eq $1^{-1}$ except $* \mathrm{mg} \mathrm{l}^{-1} \mathrm{CaCO} 3,+\mathrm{mg} \mathrm{l}^{-1}$ and ${ }^{\wedge} \mu \mathrm{g} \mathrm{l}^{-1}$.

\begin{tabular}{|c|c|c|c|c|}
\hline & Allt a'Mharcaidh & Allt Ruadh & Allt Fhernagan & Allt Coire Chaoil \\
\hline \multirow[t]{2}{*}{$\mathrm{PH}$} & 6.33 & 6.32 & 6.41 & 6.78 \\
\hline & $5.1-6.89$ & $4.99-6.94$ & $4.19-6.89$ & $5.63-7.27$ \\
\hline \multirow[t]{2}{*}{ Alkalinity* } & 2.09 & 1.86 & 2.32 & 5.94 \\
\hline & $0-9.0$ & $0-9.0$ & $0-9.0$ & $0-11.2$ \\
\hline \multirow[t]{2}{*}{ ANC } & 35 & 36 & 46 & 117 \\
\hline & $-57-105$ & $-47-119$ & $-86-178$ & $2-257$ \\
\hline \multirow{2}{*}{$\mathrm{SO}_{4}$} & 51 & 54 & 55 & 59 \\
\hline & $25-94$ & $32-92$ & $32-100$ & $33-108$ \\
\hline \multirow[t]{2}{*}{$\mathrm{NO}_{3}$} & 11 & 11 & 11 & 11 \\
\hline & $<10-50$ & $<10-49$ & $<10-109$ & $<10-43$ \\
\hline \multirow[t]{2}{*}{$\mathrm{Cl}$} & 109 & 104 & 106 & 97 \\
\hline & $28-311$ & $28-254$ & $28-536$ & $28-254$ \\
\hline \multirow[t]{2}{*}{$\mathrm{Na}$} & 125 & 126 & 134 & 204 \\
\hline & $75-217$ & $76-187$ & $70-461$ & $121-298$ \\
\hline \multirow[t]{2}{*}{$\mathrm{Ca}$} & 40 & 41 & 44 & 135 \\
\hline & $4-100$ & $28-254$ & $28-536$ & $85-254$ \\
\hline \multirow[t]{2}{*}{$\mathrm{Mg}$} & 31 & 31 & 33 & 49 \\
\hline & $14-67$ & $15-87$ & $13-129$ & $18-85$ \\
\hline \multirow[t]{2}{*}{$\mathrm{K}$} & 7 & 6 & 7 & 4 \\
\hline & $4-11$ & $3-12$ & $4-37$ & $14-21$ \\
\hline \multirow[t]{2}{*}{ TOC+ } & 1.62 & 1.37 & 1.45 & 3.92 \\
\hline & $0.1-5.10$ & $0.1-7.36$ & $0.1-11.5$ & $0.1-14.1$ \\
\hline \multirow[t]{2}{*}{$\mathrm{Al}^{\wedge}$} & 3 & 2 & 2 & 4 \\
\hline & $<1-8$ & $<1-7$ & $<1-7$ & $<1-12$ \\
\hline \multirow[t]{2}{*}{$\mathrm{Fe}^{\wedge}$} & 20 & 19 & 28.4 & 32.1 \\
\hline & $1-82$ & $0.7-69$ & $1.3-91.6$ & $3.5-105$ \\
\hline \multirow[t]{2}{*}{$\mathrm{Mn}^{\wedge}$} & 2.43 & 2.41 & 3.37 & 2.55 \\
\hline & $0.04-40$ & $0.15-27$ & $0.16-54$ & $0.14-43$ \\
\hline \multirow[t]{2}{*}{$\mathrm{Zn}^{\wedge}$} & 2.47 & 2.48 & 2.66 & 2.24 \\
\hline & $0.15-36$ & $0.11-13.2$ & $0.17-22.2$ & $0.01-11.6$ \\
\hline
\end{tabular}

\section{SEASONAL PATTERNS IN STREAM WATER CHEMISTRY}

\section{Hydrological and thermal regimes}

Event-driven changes in stream water chemistry need to be considered in the context of longer-term seasonal variations which are strongly influenced by the annual hydrological and thermal regime, as shown for the Allt a'Mharcaidh in Fig. 5. The dominance of the main snowmelt period (January-April), when flows are generally highest, is the most striking feature of the plots. During this period mean monthly run-off exceeds $70 \mathrm{~mm}$, with the maximum exceeding $130 \mathrm{~mm}$. This contrasts with the drier summer period (June-September), when flows are usually lowest. Here, mean monthly run-off falls below $50 \mathrm{~mm}$ with monthly minima less than $20 \mathrm{~mm}$. During extremely cold spells, however, groundwater may sustain flows in the stream as surface and near-surface sources of run-off freeze. Thus, all months can produce low levels of run-off. Streamwaters in the western Cairngorms are cool and the thermal regimes of the streams reflect their hydrological regimes. Mean monthly temperatures fall below $4^{\circ} \mathrm{C}$ for 4 months, with February usually being the month with coldest stream waters. Temperatures subsequently increase in March as the main melt season begins and peak at $10^{\circ} \mathrm{C}$ in July, before falling again in the late summer and early autumn. 

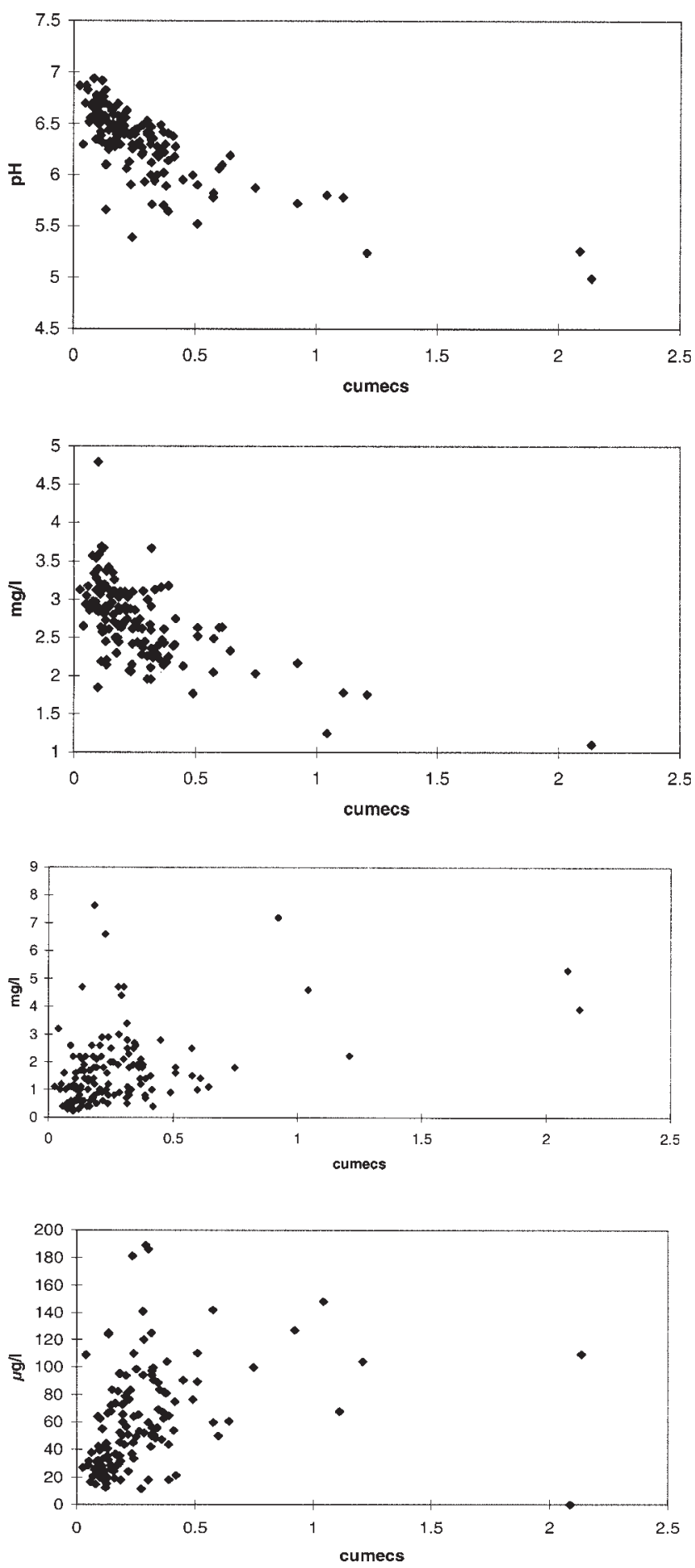

Fig. 3. Hydrological influences on stream water chemistry in the Allt Ruadh showing (a) pH, (b) Si, (c) TOC, and (d) Al concentrations.

\section{Acidity and alkalinity}

Seasonality is evident in the chemistry of the four streams (Fig. 5) and strongly reflects hydrological controls (Fig. 6).
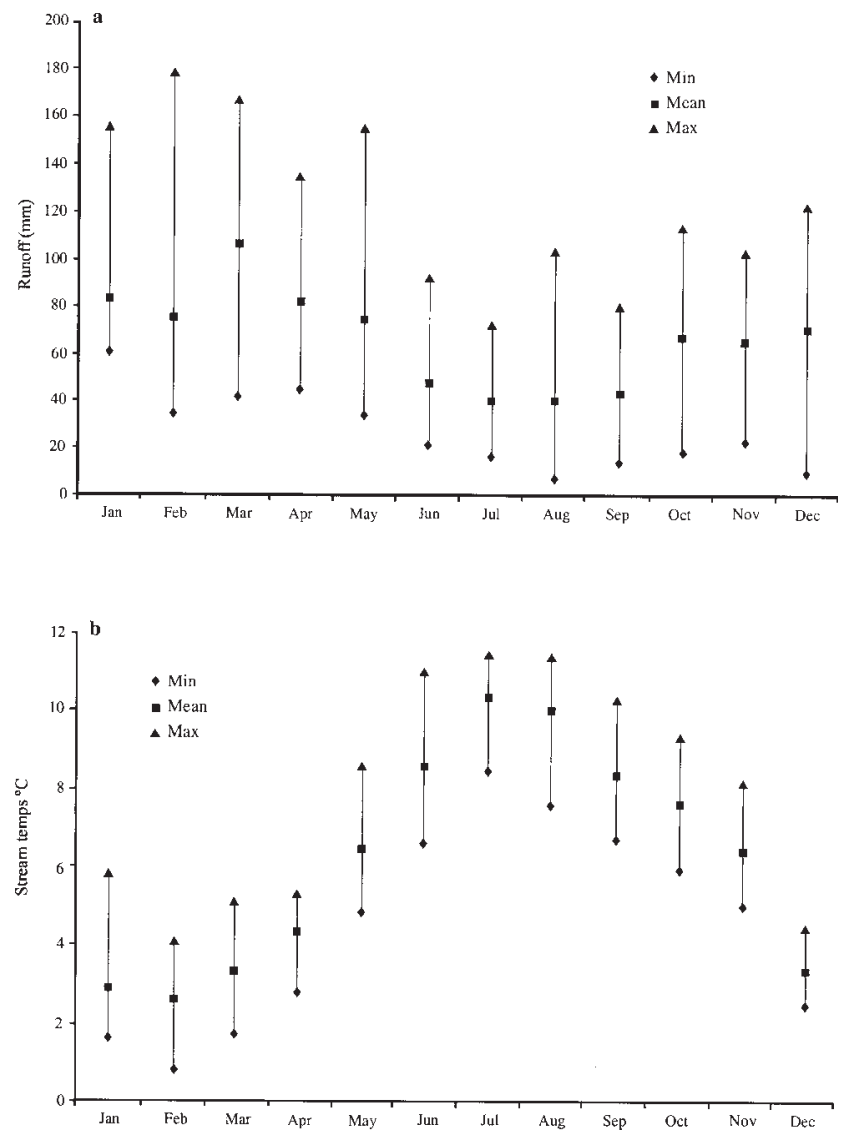

Fig. 4. Monthly mean, minimum and maximum (a) run-off and (b) temperatures in the Allt a'Mharcaidh

In general, spring appears the most distinctive season. Relative to summer and autumn samples, spring samples are pushed in a negative direction along axis 1 of the PCA, exhibiting lower alkalinity, conductivity, $\mathrm{pH}$ and major cation concentrations characteristic of higher flows. The spring may be characterised by periods of low or high discharge, depending on the degree of snow accumulation in the preceding months and ambient spring air temperatures. Base-flow maintained by groundwater predominates during the summer and autumn, with stream chemistry characterised by higher concentrations of weathering products from the bedrock, including ortho-silicate, alkalinity, $\mathrm{Ca}, \mathrm{Mg}$ and potassium (K). Mean monthly $\mathrm{pH}$ and alkalinity plots (Fig. 5b) typically show winter minima and summer maxima, which reflect the seasonal hydrological differences. Subtle differences occur in summer alkalinity mean monthly maxima. Whilst all streams have their maximum $\mathrm{pH}$ in July, peak alkalinity occurs in June for the Allt a'Mharcaidh, July for the Allt Fhernagan and Allt Ruadh and August for Allt Choire Chaoil. These subtle differences may well reflect contrasts in catchment 

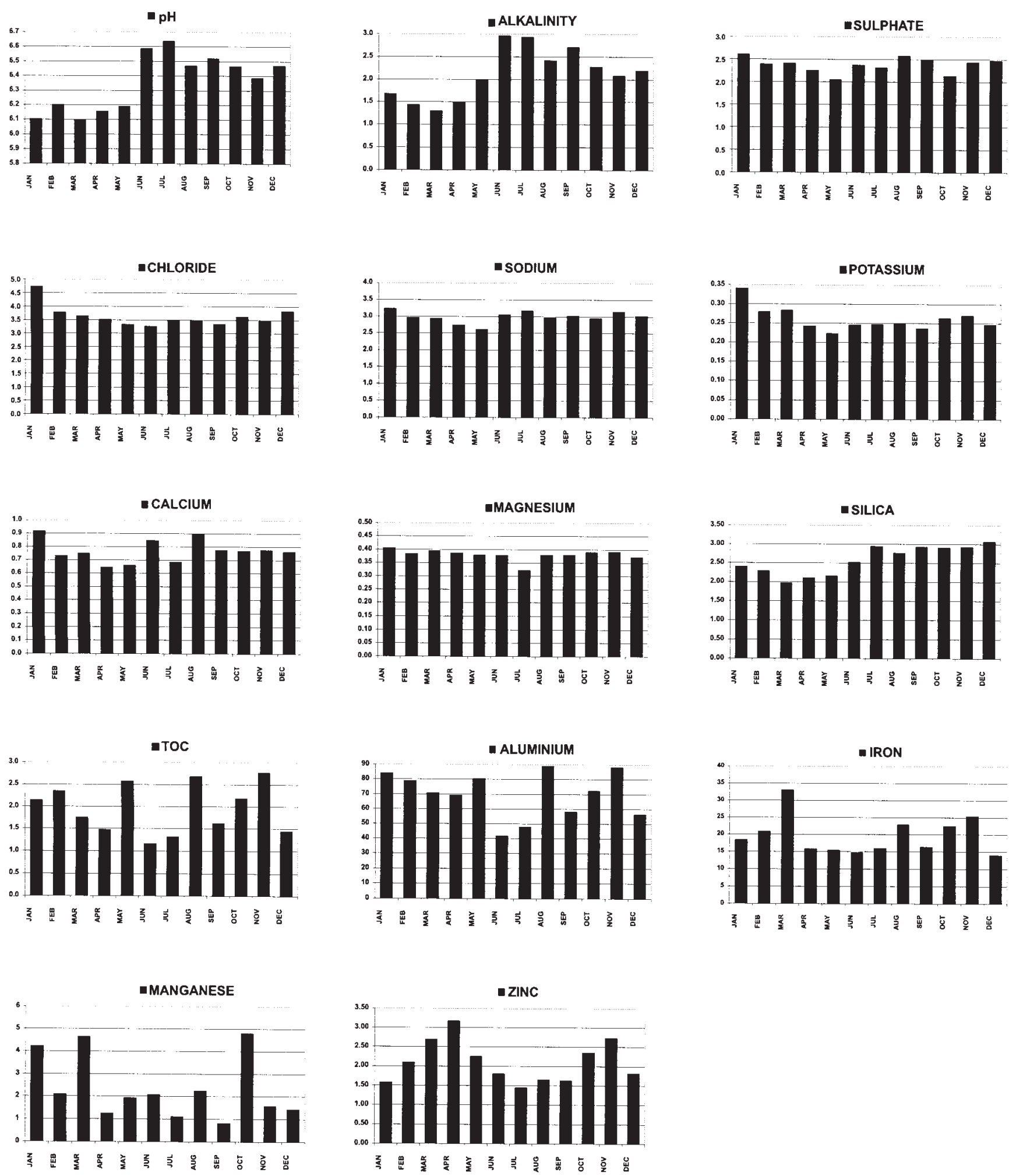

Fig. 5. Seasonal variations in water chemistry in the Allt a'Mharcaidh stream. (All units mg $l^{-1}$ except pH and Al, Fe, Mn, and Zn: ìg $l^{-1}$ ).

hydrology, such as differential snowmelt and different hydrogeological characteristics.
Anions

Of the major anions, $\mathrm{Cl}$ concentrations show a general winter maximum—spring minimum during the study (Fig. 5). 


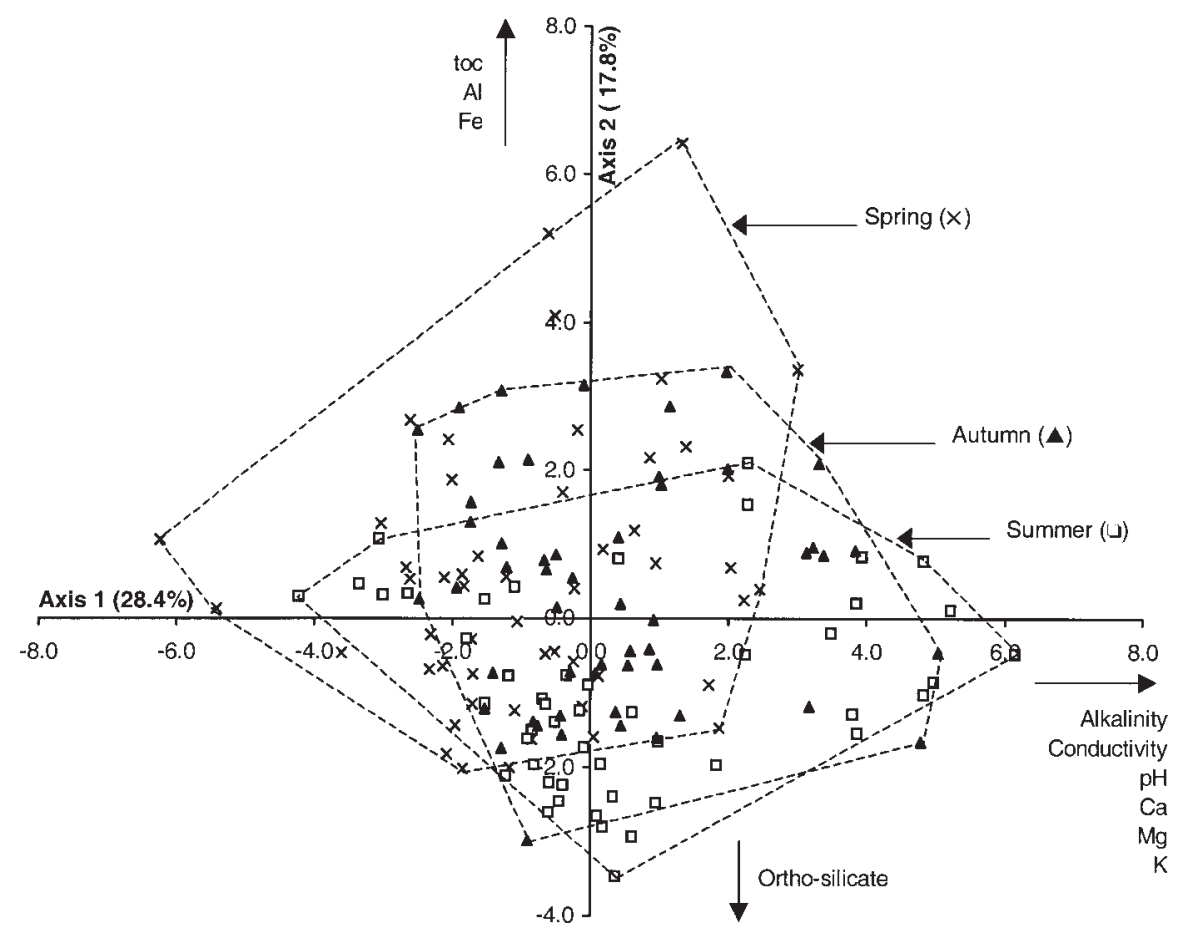

Fig. 6. Principal components analysis showing seasonality in stream chemical characteristics

Sulphate variations were similar, with May having the minimum mean monthly concentration in all four streams. Nitrate concentrations (not shown) were very low in the study streams and below detection $\left(0.1 \mathrm{mg} \mathrm{l}^{-1}\right)$ for most of the year, indicating $\mathrm{N}$ retention within the catchment vegetation and soils. Higher values were usually observed either during the early stages of snowmelt or during early autumn storm events. The winter maxima of $\mathrm{Cl}$ and $\mathrm{SO}_{4}$ are likely to reflect the higher precipitation inputs and higher rates of dry and occult deposition (particularly on snow pack surfaces) during the winter (Ferrier et al., 1994). The subsequent preferential elution from snowpacks affects the seasonal response of the main anions, especially $\mathrm{NO}_{3}$, which become depleted as melting progresses probably explaining the late spring minimum (Jenkins et al., 1993; Davies et al., 1993).

\section{Base cations}

The major cations exhibit slightly different seasonal patterns in their behaviour (Fig. 5). Peak monthly Na concentrations occur in January or February in all streams, whilst monthly minima occur in May, before rising to a secondary peak during the summer months. April is the month with the lowest mean monthly Ca concentrations in all streams, with $\mathrm{Ca}$ also exhibiting peaks in both the winter (January) and again in the summer (June to August). The patterns for $\mathrm{Mg}$ are more complex, though monthly minima tend to occur in
April/May (except for the Allt a'Mharcaidh), maxima can be in summer or winter. Potassium has a striking seasonality in the streams with clear winter maxima and summer minima.

The initial $\mathrm{Na}$ peak probably reflects the differential contribution of atmospheric inputs which will be highest during the winter and then the secondary peak will reflect higher weathering rates in groundwaters which will be highest during the summer. Again, elution of $\mathrm{Na}$ and other cations from snowpacks probably contributes to the low concentrations observed in May. Similarly, the Mg response probably reflects annual deposition inputs in the three northern streams, whilst in the Coire Chaoil (not shown) where significant sources of weatherable minerals exist, a classic weathering pattern with summer maxima is observed. The Ca response is complex though it also appears to reflect the interaction of deposition and weathering controls at different times of the year. Thus, the high summer concentrations are consistent with higher groundwater inputs, whilst the peak in January may reflect preferential elution from snowpack surfaces, or release of exchangeable cations from the catchment soils as a result of high mobile anion concentrations in snow melt (see Davies et al., 1993). In contrast, $\mathrm{K}$ patterns appear to reflect high uptake rates by vegetation in the spring and summer and the effects of flushing during the winter months. 


\section{Silicate, TOC and trace metals}

Silica concentrations also showed a general decline between March and May during the main snowmelt period in all four streams, but then increased through the summer to the late winter. This is consistent with the dilution of silicate expected at high flows where near-surface hydrological pathways in organic soil horizons predominate. The summer peak is probably suppressed by uptake by diatoms and algae in the streams (Lancaster et al., 1996), though predominant groundwater sources in the summer and autumn still increase silicate concentrations in the streams (Jarvie et al., 2001). The continued increase as the catchment wets up in the autumn appears to reflect a flushing effect, possibly of weathering products that accumulate in the catchment soils during the summer (Soulsby et al., 1999).

Total Organic Carbon concentrations exhibited complex seasonal patterns in all streams. Concentrations were at a minimum in June and July, however, high values were observed in January/February, May, August and SeptemberNovember. The controls on TOC mobilisation are clearly very complex and at various times of the year these controls vary in their relative influence (Dawson et al., 2001). Thus; hydrological pathways in organic soils in the winter period, decomposition of organic material as temperatures rise in the spring and the flushing of soils after re-wetting in the first events of late summer and early autumn may all account for pulses of TOC being observed in stream waters. The seasonal patterns of TOC were generally mirrored by $\mathrm{Al}$, presumably reflecting the dominance of organic $\mathrm{Al}$ species

Table 3. Mean abundance of the ten most numerous invertebrate taxa recorded in the four Cairngorm streams 1984-1997. Values are means across all streams calculated from 72 samples.
Taxon

Mean abundance (s.d.) per sample

\section{Simuliidae}

Baetis rhodani (Pictet)

Brachyptera risi (Morton)

Leuctra inermis Kempny

Rithrogena semicolorata

(Curtis)

Chironomidae

Amphinemura sulcicollis

(Stephens)

Naidae

Enchytaeidae

Dicranota sp.
$76.8(206.2)$

$64.4(68.26)$

$59.7(79.4)$

33.7 (40.6)

$32.8(39.3)$

$31.8(44.7)$

$24.1(28.2)$

$16.4(20.0)$

$12.4(23.0)$

$11.4(12.2)$ in western Cairngorm streams (Soulsby et al., 1997b). To a lesser extent the influence of TOC on Fe mobilisation are evident, though like manganese (Mn), these are less clear as they also depend upon the redox state and acidity of catchment soil waters for their mobilisation. Similarly, complex patterns of $\mathrm{Zn}$ in stream water occur, probably reflecting random variation in atmospheric inputs and subsequent transport as organic complexes (Neal et al., 1997)

\section{INVERTEBRATE COMMUNITIES}

Invertebrate communities in the four streams comprised species typical of slightly acidic upland waters (Table 3 ). Inter-catchment and seasonal patterns in invertebrate community characteristics parallel hydrological and hydrochemical ones (Fig. 7). Invertebrate communities found in the Allt Coire Chaoil were distinct from those of the other catchments, separated in the dimension described by $\mathrm{pH}$, alkalinity and TOC arrows (Fig. 7a). Thus, intercatchment differences in invertebrate communities reflect primarily differences in these three variables which, in turn, reflect differences in underlying geology. Seasonal separation of invertebrate communities on the CCA plot (Fig. 7b) is primarily with respect to temperature and discharge. Note that arrows for temperature and discharge point in opposite directions; this means that periods of high flow are typically characterised by low temperatures and vice versa. Spring appears the most distinctive season for two reasons. First, the polygon grouping spring samples together stands apart from those of the summer and autumn. Second, the spring polygon occupies a larger area of ordination space. This is a result of the greater distances between individual sample points. As these Euclidean distances reflect sample species compositions, the significantly greater distances between spring samples (Freidman Test $p<0.01$ ) mean that spring invertebrate samples are typically more variable than those found in other seasons.

Although CCA ordinations depicted in Fig. 7 illustrate the key ways in which catchments and seasons differ, they explain relatively little of the overall variation in invertebrate sample data over the 13 year period (eigenvalues for axes 1 and 2 are 0.2 and 0.089 , respectively). This low level of explanation may indicate that variables other than those measured have an important influence on invertebrate community characteristics. It could also indicate that controls differ between catchments or that conditions other than those on the day of sampling are important. An ordination of only the Allt a'Mharcaidh data using indices of variation over the preceding two months yielded 
Seasonality, water quality trends and biological responses in four streams in the Cairngorm Mountains, Scotland

(a)

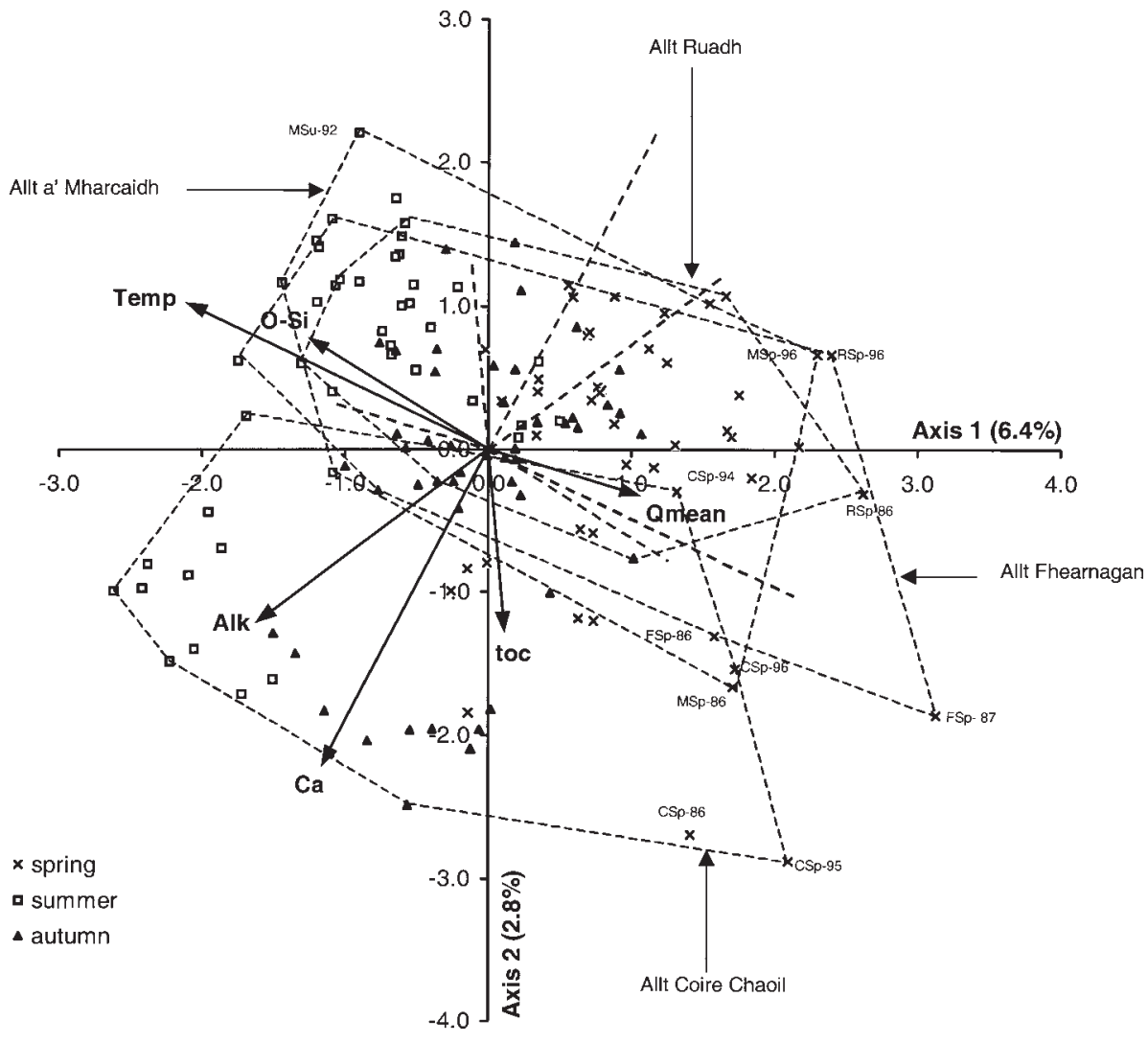

(b)

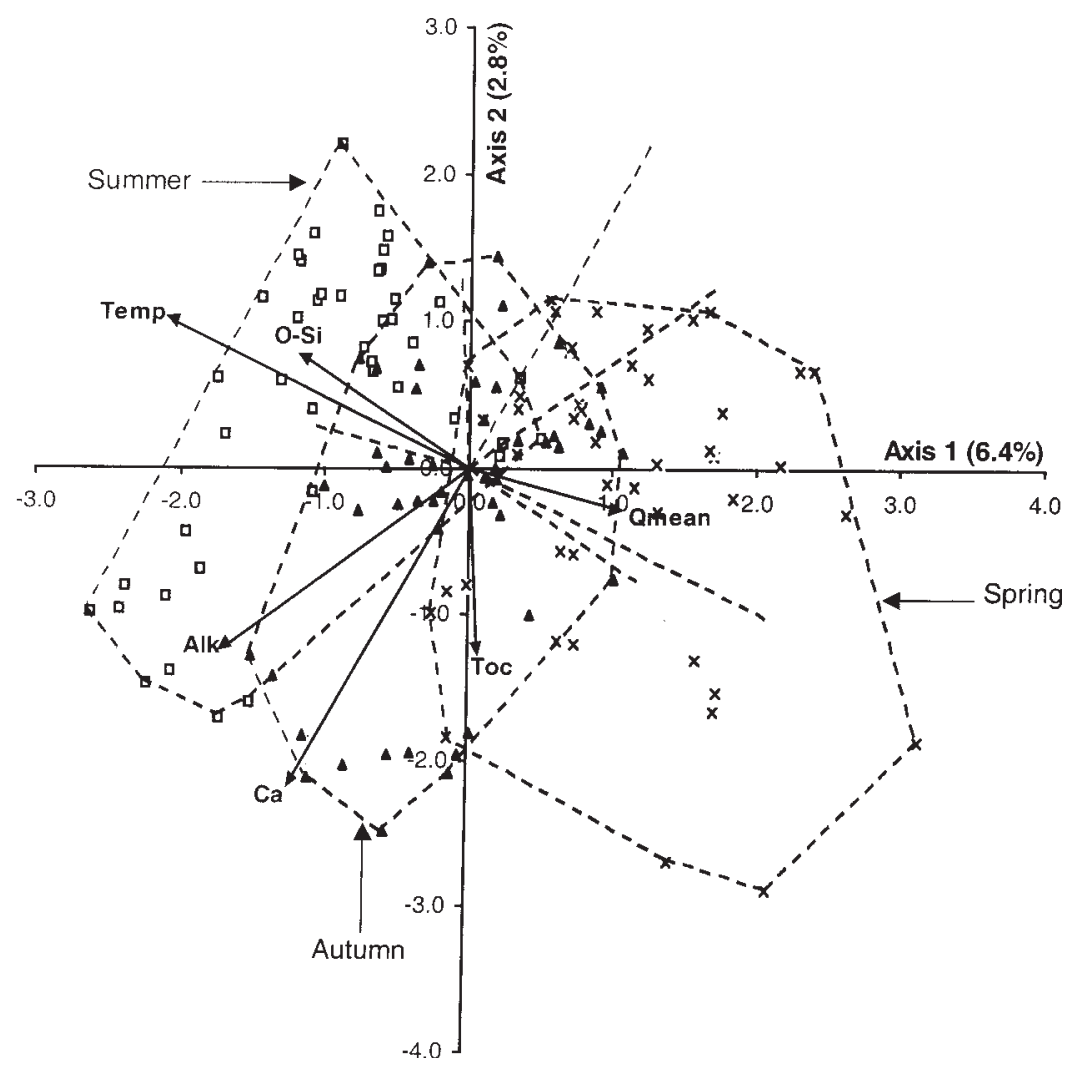

Fig. 7. Canonical Correspondence Analysis of Cairngorm stream invertebrate, hydrological and chemical data. Samples are separated by (a)catchment and (b) season. 
eigenvalues of 0.35 and 0.309 , respectively, for axes 1 and 2; this compares with 0.32 and 0.14 using date specific environmental data for the Mharcaidh. This suggests that variation in invertebrate sample data, including seasonal and any long term variation, correlates most strongly (higher eigenvalues) with variation in environmental conditions in the two months immediately preceding sampling.

\section{LONG-TERM TRENDS IN HYDROLOGY AND WATER CHEMISTRY}

Patterns in hydrological and thermal regimes in the Allt a'Mharcaidh (Fig. 8) over the sampling period were used to help interpret trends in chemical data (Figs. 9 and 10). LOWESS plots of stream water chemistry were produced using one year smoothing for the Allt Ruadh (Fig. 9) and long-term smoothing for all streams (Fig. 10). The significance levels of directional trends derived from the seasonal Kendall test are summarised for selected chemical species in Table 4.

\section{Hydrological and thermal trends}

The hydrological and thermal regimes of the Allt a'Mharcaidh between 1985 and 1997 were characterised by marked inter-annual variation. In particular, winter snowpack accumulation and summer low flows exert a strong influence (Fig. 8). Given geographical proximity and the regional nature of climatic influences, this probably provides an insight into the hydroclimatological factors affecting the hydrochemistry of the other three streams. Between 1985 and 1997, cold (Fig. 8a) and snowy winters, such as those of 1985/1986, 1987/1988, 1990/1991 and 1993/1994, have been interspersed by much milder winters (1988/1989, 1989/1990, 1991/1992 and 1997/1998). The early years of the study were characterised by relatively cool summers (notably 1987 and 1988), but the summers of 1989-1991 and 1995 and 1997 were all warm and relatively dry. On the whole, both air and stream temperatures have tended to increase in the study area during the study period, both in terms of mean annual and mean spring temperatures. Although the length of record is insufficient to identify an unequivocal trend in the Allt a'Mharcaidh, a 30-year temperature record for the Girnock burn in the eastern Cairngorms has been analysed and a clear increase in mean annual and spring temperatures has been identified (Langan et al., 2001).

These climatic factors have clearly influenced the hydrological variation over the study period. The period 1985-1988 was relatively wet, with the summer of 1989 being exceptionally dry (Fig. 8c). Subsequently, the start of (a)

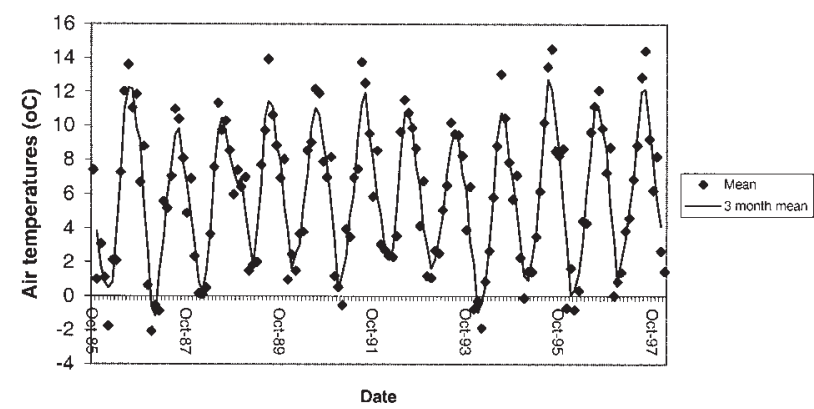

(b)

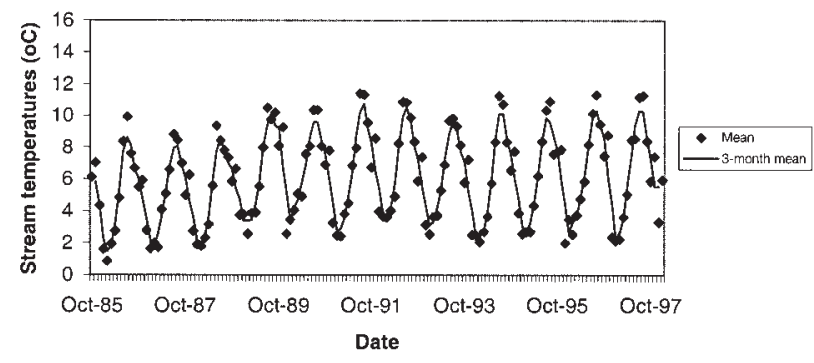

(c)

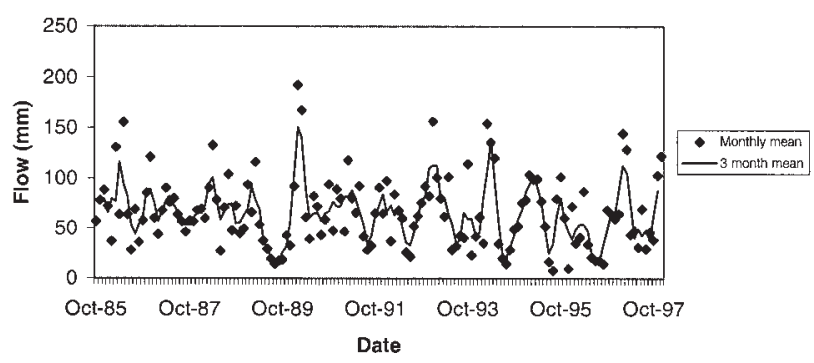

Fig. 8. Hydrological and thermal regimes in the Allt a'Mharcaidh 1985-1997. Plots show monthly average and three monthly running means for (a) air temperatures, (b) stream temperatures and (c) stream run-off.

1990 was exceptionally wet, producing the highest monthly stream flows in the data record. Although wet winters occurred in 1992/1993 and 1993/1994, however, a number of relatively drier summers and winters have characterised much of the 1990s. Similar general hydrological patterns have been observed elsewhere in the UK where the influence of climatic variations on stream chemistry has been identified (Robson and Neal, 1996; Langan et al., 1997; Miller et al., 2001).

\section{Acidity and alkalinity}

Stream $\mathrm{pH}$ shows an increasing trend over the data period, reflected in higher summer peaks and a reduction in winter minima (Fig. 9), though trends are statistically significant only for the Allt Fhernagan and Allt Ruadh (Table 4). These trends may be related to decreasing levels of $\mathrm{S}$ deposition 

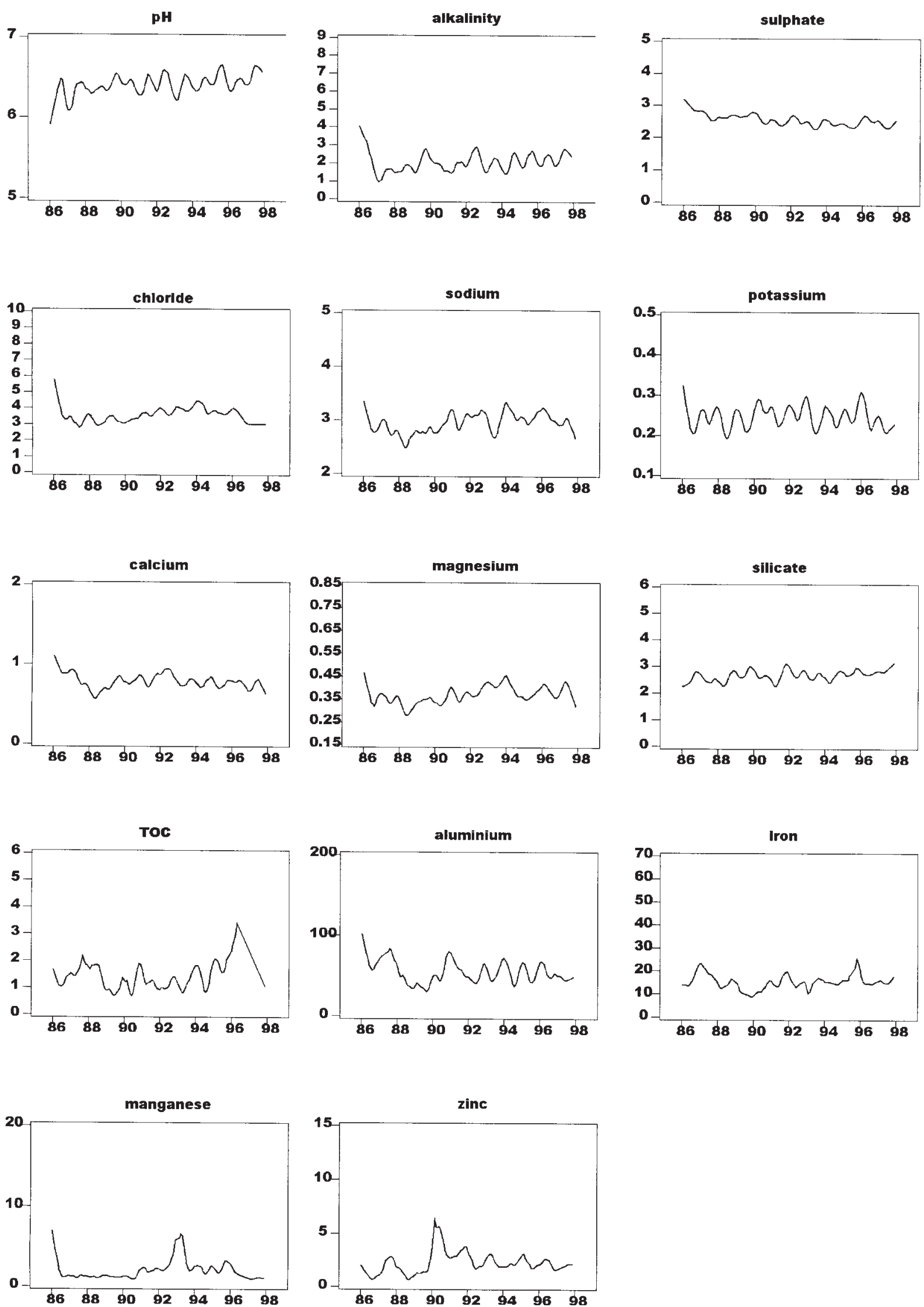

Fig. 9. Long-term variations using one year smoothing curves in Allt Ruadh. (All units $\mathrm{mg}^{l^{-1}}$ except pH, and Al, Fe, Mn, and Zn: ìg $l^{-1}$ ). 
$\mathrm{pH}$

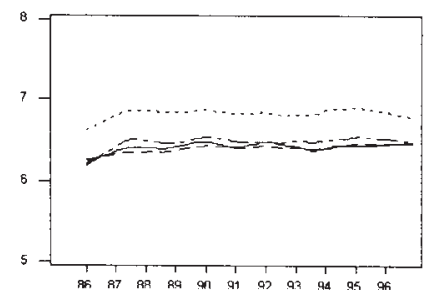

chloride

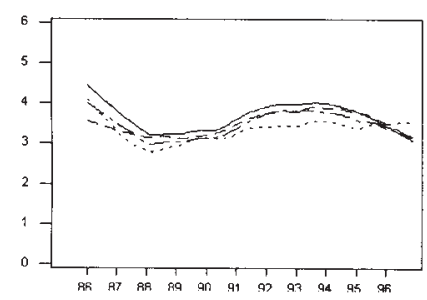

calcium

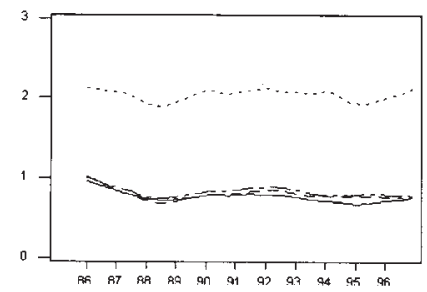

TOC

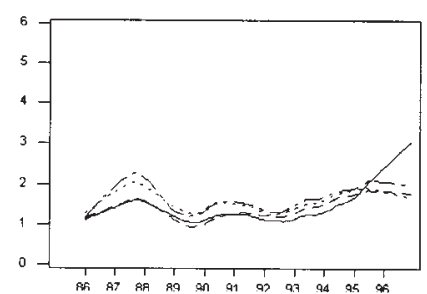

manganese

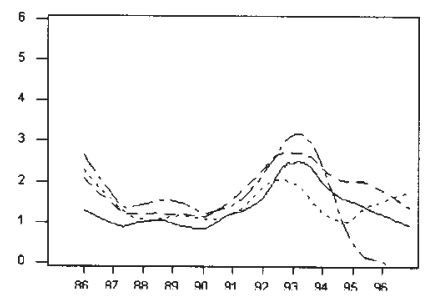

alkalinity

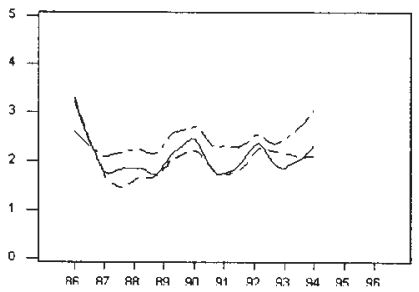

sodium

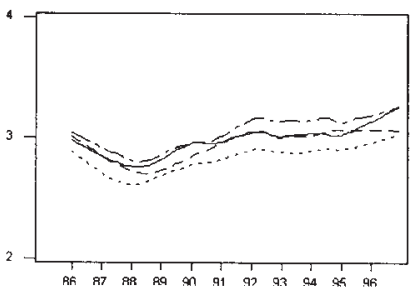

magnesium

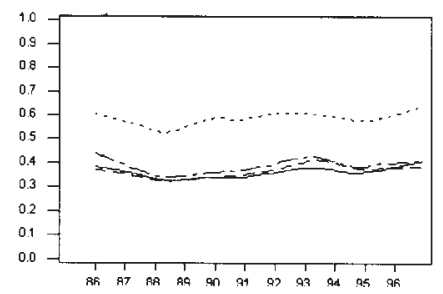

aluminium

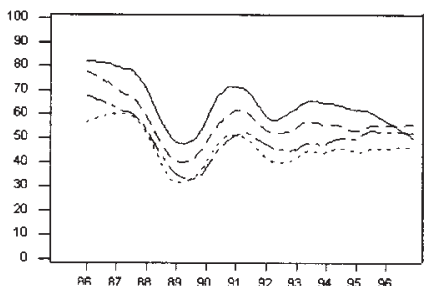

$\operatorname{zinc}$

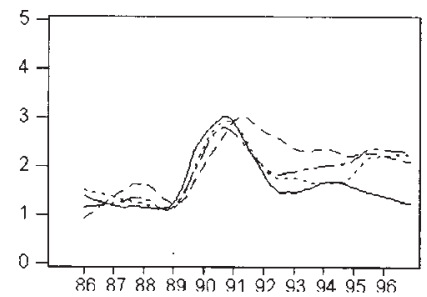

sulphate

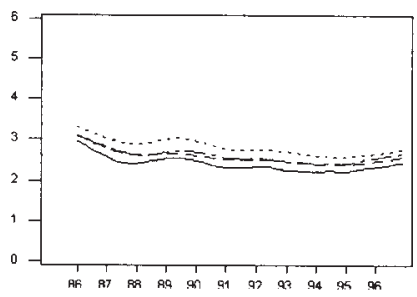

potassium

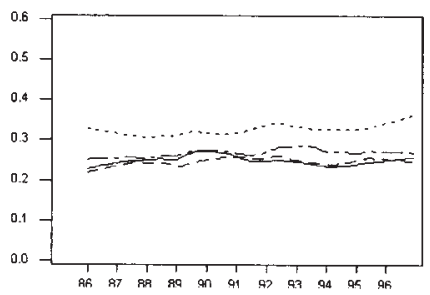

silica

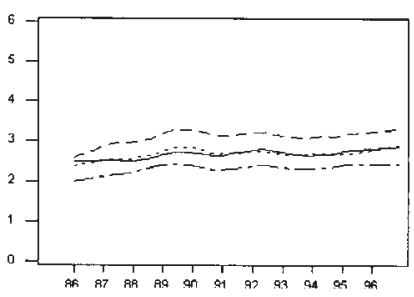

iro

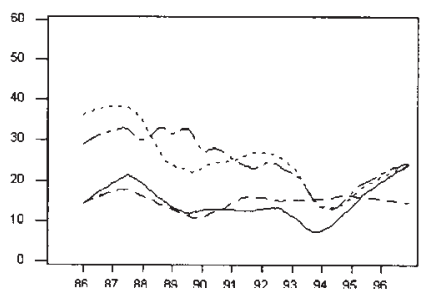

Fig. 10. Long-term trends in all four study streams. (All units $m g l^{-1}$ except $p H$, and $A l, F e, M n$, and $\mathrm{Zn}$ : ig $l^{-1}$ ) 
Table 4. Significance of trends in the study streams $(* \mathrm{p} \leq 0.01, * * \mathrm{p} \leq 0.001)$

\begin{tabular}{lllllllll}
\hline & $p H$ & Alkalinity & SO4 & Si & $N a$ & $C a$ & $M g$ & $K$ \\
\hline Allt a'Mharcaidh & 0.098 & 1.851 & $-2.787^{* *}$ & 0.630 & $3.548^{* *}$ & $-2.011^{*}$ & $4.332^{* *}$ & -0.284 \\
Allt Ruadh & $2.420^{*}$ & $3.833^{* *}$ & $-4.360^{* *}$ & 1.914 & $4.125^{* *}$ & -0.720 & 3.896 & -0.584 \\
Allt Fhernagan & $2.286^{*}$ & $-2.113^{*}$ & $-4.389^{* *}$ & -0.126 & $3.260^{* *}$ & $-1.435^{*}$ & 3.523 & 3.161 \\
Allt Coire Chaoill & 0.628 & 1.274 & $-4.389^{* *}$ & 0.334 & $4.887^{* *}$ & 0.579 & $2.236^{*}$ & 3.161 \\
\hline
\end{tabular}

in the area (see below), or may relate to the hydrological effects of cool, wet winters and summers at the start of the study and the warmer drier years at the end. Similar interannual seasonal variation was observed for alkalinity, but a consistent trend was less evident.

\section{Anions}

The most obvious trend was the previously reported ( $c f$. Soulsby et al., 1997) decline in $\mathrm{SO}_{4}$ levels (statistically significant in all catchments), assumed to be in response to declining $\mathrm{S}$ emissions. The seasonal effects of higher $\mathrm{SO}_{4}$ levels in winter events are evident in the LOWESS plots as are the effects of lower summer concentrations (Fig. 9). Unfortunately, poor analytical precision in the $\mathrm{Cl}$ data limit interpretation. Nevertheless, weak seasonality was evident and the higher levels of $\mathrm{Cl}$ deposition reported in the early 1990s for much of the UK (cf. Robson and Neal, 1996; Langan et al., 1997) seem to be reflected in the stream water response (Fig. 10). The high levels of $\mathrm{Cl}$ deposition has been associated nationally with an anomalously high frequency of westerly weather systems affecting the UK, possibly reflecting the influence of the North Atlantic Oscillation (Evans et al., 2001). Despite some relatively high levels of leaching in the mid-1980s, the paucity of samples with detectable $\mathrm{NO}_{3}$ levels precluded trend analysis.

\section{Base cations}

Visually evident declines in Ca were observed in all streams but these were only statistically significant in the Allt a'Mharcaidh and Allt Fhernagan (Table 4). It is possible that a $\mathrm{Ca}$ decline is occurring in response to declining $\mathrm{S}$ inputs, if $\mathrm{Ca}$ is a balancing cation. Despite the area experiencing drier weather, which might be expected to increase $\mathrm{Ca}$ concentrations as a result of increased groundwater influence, the fact that a declining trend is evident adds some support to a deposition-related hypothesis. A statistically significant increasing trend in $\mathrm{Na}$ concentrations is evident in all catchments. This could reflect a lagged response to high levels of sea-salt deposition in the early 1990s, with cation exchange reactions in the catchment soils temporarily retaining Na. Alternatively, it could reflect hydrological influences with lower flows increasing the contribution of groundwater to stream flows in the 1990s. Magnesium and K show little evidence of any consistent trends in the study streams, though significant increases in $\mathrm{Mg}$, similar to $\mathrm{Na}$, are indicated for the Mharcaidh and Coire Chaoil.

\section{Silica, TOC and trace metals}

Silica exhibited a weak increasing trend over the monitoring period. Marked variations in the responses of TOC, $\mathrm{Al}$ and $\mathrm{Zn}$ were observed. The TOC and Al peaks may reflect the occurrence of warm summers, with low concentrations following cool, wet years. Since 1993, an increasing trend in TOC has been observed which probably reflects increasing decomposition rates in the warmer and drier conditions that have prevailed. The patterns of $\mathrm{Fe}$ and $\mathrm{Mn}$ are extremely complex, probably reflecting the effects of redox reactions in the catchments soils and organic complexation (Heal, 2001). The variations in $\mathrm{Zn}$, however, probably reflect atmospheric inputs (Robson and Neal, 1996).

\section{Implications}

The varied and complex response of different chemical species in the four streams shows interesting patterns of inter-annual variations in stream hydrochemistry. As demonstrated by Robson and Neal (1996), even data over a 13-year time span is insufficient to disaggregate fully the effects of directional, cyclical/random and hydrological influences on stream water quality. Moreover, Burt (1994) suggests environmental data sets of a decade-or-so identify most usefully the system response to annual variations and anomalous events, whilst $>30$ years data is required to identify directional trends with conviction. In the western Cairngorms, declining $\mathrm{SO}_{4}$ concentrations appear to be consistent with directional environmental change in response to emission controls. The effects of inter-annual climatic, deposition and hydrological variations influence most other 
solutes with the result that identification of controls in the absence of detailed process studies is extremely difficult.

Invertebrate communities are well known to vary seasonally, largely a reflection of variation in the life-cycles of the constituent species. For example, the stonefly Brachyptera risi was among the most abundant of animals in winter samples but absent from summer ones. Thus, the strong seasonality in the communities found in the four streams was expected. Similarly, as stream invertebrate distributions are known to reflect, among other things, water chemistry, inter-catchment differences paralleling geological differences were not unexpected. More interestingly, ordination using indices of variation in stream chemical and hydrological conditions yielded higher eigenvalues; i.e. variation in environmental conditions appeared more important than average values on the day of sampling. Although chemical data reported here and elsewhere suggest that there are long-term trends in these and other Cairngorm streams, both Lancaster et al. (1996) and Gibbins et al., (2001) were unable to detect any long-term trends in invertebrate communities. While CCA analyses suggest that invertebrate communities vary seasonally and inter-annually in a way that most closely correlates with environmental variation, therefore, they appear stable over longer time periods. This stability is also evidenced by the work of Soulsby et al. (1997b) who did not detect acid-related impoverishment in invertebrate faunas of the four Cairngorm streams.

The current state of the invertebrate communities in the study streams contrasts with the acidification-impacted high altitude lochs. Whilst increasing deposition at high altitudes probably contributes to this, shallow soils, sparser drift cover and short hydrological residence times will all increase vulnerability to acidification. At the stream sites where invertebrates were monitored in this study, increasing drift cover and increased contribution of longer-residence time, higher alkalinity groundwater increases buffering and so reduces vulnerability.

This study has shown that the winter period, and in particular snowmelt, strongly influences both the hydrological regime and hydrochemical seasonality of streams in the western Cairngorms. Although others have examined the influence of seasonal snowpack dynamics on the quantity and quality of streamflows (Jenkins et al., 1993; Soulsby et al., 1997), this study highlights the dominance of such processes on the hydrochemical regime of the streams. In this context, it is notable that the most distinctive and variable invertebrate communities were found in the spring (cf. Turnbull et al., 1995) and that the highest eigenvalues were for ordinations using variation in hydrological and hydrochemical conditions over preceding (i.e. late winter/early spring) periods. This importance of the seasonal flow regime during specific periods is becoming increasingly apparent. Studies such as that of Webb et al. (2001) are improving our understanding of the importance of flow variation for aquatic ecosystems. This understanding is required to help assess the ecological impacts of flow changes as part of the EU Water Framework Directive. The key importance of hydrochemical seasonality needs to be recognised, however, if the effects of seasonal flow variation on aquatic communities is to be fully understood.

\section{Acknowledgements}

This work has been funded by the Leverhulme Trust, whose support is gratefully acknowledged. The Scottish Environment Protection Agency carried out most of the chemical sampling and analysis reported in the paper and the help of Roger Owen and Mike Davidson in accessing this data is warmly appreciated. Rachel Helliwell of the Macaulay Land Use Research Institute is thanked for access to flow data. The streams now form part of the Feshie study which forms part of the National Infrastructure for Catchment Hydrological Experiments (NICHE) funded by NERC.

\section{References}

Aulenbach, B.T., Hooper, R.P. and Bricker, O.P., 1996. Trends in the chemistry of precipitation and surface water in a national network of small watersheds. Hydrol. Process., 10, 151-181.

Battarbee, R.W., Flower, R.J., Stevenson, A.C., Jones, V.J., Harriman, R. and Appleby, P.G., 1988. Diatom evidence and chemical evidence for reversibility of acidification of Scottish Lochs. Nature, 332, 530-532.

Buckton, S.T., Brewin, P.A., Lewis, A., Stevens, P. and Ormerod, S.J., 1998. The distribution of dippers, Cinclus cinclus (L.), in the acid-sensitive region of Wales, 1984-95. Freshwater Biol., 39, 387-396.

Burt, T.P., 1994. Long-term study of the natural environment perceptive science or mindless monitoring? Prog. Phys. Geog., 18, 475-496.

Clausen, B. and Biggs, B.J.F., 1997. Relationships between benthic biota and hydrological indices in New Zealand streams. Freshwater Biol., 38, 327-342.

Davies. T.D., Tranter, M., Blackwood, I.L. and Abrahams, P.W., 1993. The character and causes of a pronounced snow-melt induced acidic episode in a stream in a Scottish subarctic catchment. J. Hydrol., 146, 267-300.

Dawson, J.J.C., Bakewell, C. and Billett, M.F., 2001. Is in-stream processing an important control on spatial changes in headwater carbon fluxes. Sci. Total Envir., 265, 153-169.

Doughty, R., 1989. Baseline study of acidified waters in Scotland. Report to the Department of Environment. Research Contract No. PECD7/10/104, 72 pp.

Dunn, S.M. and Langan, S.J., 1998. Climate, snow and the water resources of a major Scottish river. In: Proc. 2nd Int. Conf. on Climate Water (N. Lemmela and N. Helenius (Eds.)), 178-187. Espoo, Finland. 
Edwards, R.W., Gee, A.S. and Stoner, J.H. (Eds.), 1990. Acid waters in Wales. Kluwer Academic Publishers, London, 337 pp.

Edwards R.W., Ormerod S.J. and Turner C., 1991. Field experiments to assess the biological effects of pollution episodes in streams. Verhandlungen der Internationalen Vereinigung feur Theoretische und Angewandte Limnologie, 24, 1734-1737.

Evans, C.D., Monteith, D.T. and Harriman, R., 2001. Long-term variability in the deposition of marine ions at west coast sites in the UK acid waters monitoring network: impacts on surface water chemistry and significance for trend determination. Sci. Total Envir., 265, 115-131.

Ferrier, R.C., Jenkins, A. and Elston, D., 1994. The composition of rime ice as an indicator of the quality of winter deposition. Environ. Pollut., 87, 1-8.

Gibbins, C.N., Dilks, C.F., Malcolm, R., Soulsby, C. and Juggins, S., 2001. Relationships between invertebrates and hydrological variability in Cairngorm mountain streams. Hydrobiologia, (in press).

Gordon, J.E., Thompson, D.B.A., Haynes, V., Brazier, V. and MacDonald, R., 1998. Environmental sensitivity and conservation management in the Cairngorm mountains, Scotland. Ambio, 27, 335-344.

Grew, H. and Werritty, A., 1995. Changes in flood frequency and magnitude in Scotland 1964-1992. Proc. $5^{\text {th }}$ Nat. Hydrol. Symp. British Hydrological Society, 3.1-3.9.

Harriman, R., Gillespie, E. and Morrison, B.R.S., 1990. Factors affecting fish survival in Scottish catchments. In: The Surface Water Acidification Programme, B.J. Mason (Ed.), 343-355. Cambridge University Press. Cambridge, UK.

Harriman, R., Morrison, B.R.S., Birks, J., Allott, T.E.H. and Flower, R.J., 1995. Long-term chemical and biological trends in Scottish streams and lochs. Water Air Soil Pollut, 85, 701706.

Heal, K., 2001. Manganese and land use in upland catchments in Scotland. Sci. Total Envir., 265, 169-181.

Helliwell, R.C., Ferrier, R.C. and Kernan, M., 2001. Interaction of nitrogen deposition and land use on soil and water quality in Scotland: issues of spatial variability and scale. Sci. Total Envir., 265, 51-65.

Hirsch, R.M., Slack, J.R. and Smith, R.A., 1982. Techniques of trend analysis for monthly water quality data. Water Resour. Res., 18, 107-121.

Hornung, M., Rodda, F. and Langan, S.J., 1990. A review of small catchments in Western Europe. Air Pollution Response Report No. 28, ECE Brussels, 98 pp.

Jarvie, H., Neal, C., Smart, R., Owen, R., Fraser, D., Forbes, I. and Wade, A., 2001. Use of continuous water quality records for hydrograph separation and to assess short-term variability and extremes in acidity and dissolved carbon dioxide for the River Dee, Scotland. Sci. Total Envir., 265, 85-99.

Jenkins, A., 1999. The end of acid reign? Nature, 401, 537-538.

Jenkins, A., Ferrier, R.C. and Harriman. R., 1993. Meltwater chemistry and its impact on stream water quality. Hydrol. Process., 8, 335-349.

Jones, V.J., Flower, A.J., Appleby, P.J., Natkanski, J., Richardson, N., Rippey, B., Stevenson, A.C. and Battarbee, R.W., 1993. Palaeolimnological evidence for the acidification and atmospheric contamination of lochs in the Cairngorm and Lochnagar areas of Scotland. J. Ecol., 81, 3-24.

Jongman, R.H.G., ter Braak, C.J.F. and Van Tongeren, O.F.R. (Eds.), 1995. Data analysis in landscape and community ecology. Cambridge University Press, UK, 352 pp.

Juggins, S., Flower, R.J. and Battarbee, R.W., 1996. Palaeolimnological evidence for recent chemical and biological changes in U.K. Acid Waters Monitoring Network sites. Freshwater Biol., 36, 203-219.

Lancaster, J., Real, M., Juggins, S., Monteith, D.T., Flower, R.J. and Beaumont, W.R.C., 1996. Monitoring temporal changes in the biology of acid waters. Freshwater Biol., 36, 179-201.

Langan, S.J., Hirst, D., Helliwell, R. and Ferrier, R., 1997. A scientific review of the Loch Dee water quality and quantity data sets. Report No. SR 97 (01) F. MLURI, Aberdeen, 59 pp.

Langan, S.J., Donald, L., Donaghy, M., Hay, D. and Soulsby, C., 2001. Variation in river water temperatures trends in a Scottish highland stream over a 30 year period. Sci. Total Envir., 265, 195-209.

Mason, C.F., 1990. Biological aspects of freshwater pollution. In: Pollution: causes, effects and control, (R.M. Harrison (Ed.), 99-121. Royal Society of Chemistry, Cambridge, UK.

Miller, J.D. and Hirst, D., 1998. Trends in concentrations of solutes in an upland catchment in Scotland. Sci. Total Envir, 216, 7788.

Miller, J.D., Adamson, J.K. and Hirst, D., 2001. Trends in stream water quality in Environmental Change Network upland catchments: the first five years. Sci. Total Envir., 265, 27-39.

Moldan, B. and Cerny, J., 1994. Biogeochemistry of small catchments: a tool for environmental research. Wiley, Chichester, UK, 419 pp.

Monteith, D.T. and Evans, C.D., 2000. UK Acid Waters Monitoring Network: 10 Year Report. ENSIS Publishing, London 124 pp.

Neal, C., Hill, T., Hill, S. and Reynolds, B., 1997. Acid neutralising capacity measurements in surface and groundwaters in the upper River Severn, Plynlimon: from hydrograph splitting to water flow pathways. Hydrol. Earth Syst. Sci., 1, 687-696.

Ormerod, S.J. and Jenkins, A., 1994. The biological effects of acid episodes. In: Acidification of freshwater ecosystems, C.E.W. Steinberg and R.F. Wright (Eds.). Dahlem Workshop Report No. 14, Wiley, Chichester, UK, 259-274.

Palmer, M.W., 1993. Putting things in even better order: The advantages of canonical correspondence analysis. Ecology, 74, 2215-2230.

Reynolds, B., Renshaw, M., Sparks, T.H., Crane, S., Hughes, S., Brittain, S.A. and Kennedy, V.H., 1997. Trends and seasonaility in streamwater chemistry in two moorland catchments of the upper Wye, Plynlimon. Hydrol. Earth Syst. Sci., 1, 571-581.

Robson, A.J. and Neal, C., 1996. Water quality trends at an upland site in Wales, UK, 1983-1993. Hydrol. Process., 10, 183-203.

Sagar, P.M., 1986. The effects of floods on the invertebrate fauna of a large unstable braided river. N.Z. J. Mar. Freshwater Res., 20, 36-47.

Soulsby, C. and Dunn, S.M., 2001. Towards integrating tracer studies with conceptual catchment scale models: recent insights from a sub-arctic catchment in the Cairngorm mountains, Scotland. Hydrol. Process., (in press).

Soulsby, C., Helliwell, R.C., Ferrier, R.C., Jenkins, A. and Harriman, R., 1997a. Seasonal snowpack influence on the hydrology of a subarctic catchment in Scotland. J. Hydrol., 192, 17-32.

Soulsby, C., Turnbull, D.A., Hirst, D., Langan, S.J. and Owen, R., 1997b. Reversibility of stream acidification in the Cairngorm region of Scotland. J. Hydrol., 195, 291-311.

Soulsby, C., Chen, M., Ferrier, R.C., Helliwell, R.C., Jenkins, A. and Harriman, R., 1998. Hydrogeochemistry of shallow groundwater in an upland Scottish catchment. Hydrol. Process., 12, 1111-1118.

Soulsby, C., Malcolm, R., Helliwell, R.C., Ferrier, R.C. and Jenkins, A., 1999 Influence of springs on the hydrogeochemistry of mountain streams in the Cairngorms, Scotland. Hydrol. Earth Syst. Sci., 3, 409-419. 
Soulsby, C., Malcolm, R., Helliwell, R., Ferrier, R.C. and Jenkins, A., 2000. Isotope hydrology of the Allt a'Mharcaidh catchment, Cairngorms, Scotland. Hydrol. Process., 14, 747-762.

Stoddard, J.L., Jeffries, D., Lukewille, S., Clair, T.A., Dillon, P.J., Driscoll, C.T., Forsius, M., Johanessen, M., Kahl, J.S., Kellogg, J.S., Kemp, A., Mannio, J., Monteith, D.A., Murdoch, P.S., Patrick, S., Rebsdorf, A., Skjelkvåle, B.L., Stainton, M.P., Traaen, T., van Dam, H., Webster, K.E., Wieting, J. and Wilander, A., 1999. Regional trends in aquatic recovery from acidification in North America and Europe. Nature, 401, 575-577.

ter Braak, C.J.F., 1986. Canonical correspondence analysis: A new eigenvector technique for multivariate direct gradient analysis. Ecology, 67, 1167-1179.

ter Braak, C.J.F. and Verdonschot, P.F.M., 1995. Canonical correspondence analysis and related multivariate methods in aquatic ecology. Aquat. Sci., 57, 255-259.

Tipping, E., Carrick, T.R., Hurley, M.A., James, J.B., Lawlor, A.J., Lofts, S., Rigg, E., Sutcliffe, D.W. and Woof, C., 1998. Reversal of acidification in upland waters of the English Lake District. Environ. Pollut., 103, 143-151.
Turnbull, D., Soulsby, C., Langan, S.J., Owen, R. and Hirst, R., 1995. Macroinvertebrate status in relation to catchment characteristics and critical loads for freshwaters. Water Air Soil Pollut., 85, 2461-2466.

Wade, A.J., Neal, C., Soulsby, C., Smart, R.P., Langan, S.J. and Cresser, M.S., 1999. Modelling streamwater quality under varying hydrological conditions at different spatial scales. $J$. Hydrol., 217, 266-283.

Waters, D. and Jenkins, A., 1992. Impacts of afforestation on water quality trends in two catchments in mid-Wales. Environ. Pollut., 77, 167-172.

Webb, J.H., Gibbins, C.G., Moir, H. and Soulsby, C., 2001. Spatial patterns of discharge utilisation by spawning female Atlantic salmon: implications for flow allocation. J. CIWEM., 15, 1-8.

Wheater, H.S., Tuck, S., Ferrier, R.C., Jenkins, A., Kleissen, F.M., Walker, T.A.B. and Beck, M.B., 1993. Hydrological flow paths at the Allt a'Mharcaidh catchment: an analysis of plot and catchment scale observations. Hydrol. Process., 7, 359-371. 